\title{
IDENTIFIKASI PENGELOMPOKKAN KONDISI PERMUKAAN JALAN MENGGUNAKAN ALGORITMA K-MEANS
}

\author{
Siti Asmiatun ${ }^{1}$, Nur Wakhidah ${ }^{2}$ \\ Program Studi Teknik Informatika \\ Fakultas Teknologi Informasi Dan Komunikasi Universitas Semarang \\ E-Mail: ${ }^{1}$ siti.asmiatun@usm.ac.id, ${ }^{2}$ ida@usm.ac.id
}

\begin{abstract}
Abstrak
Kondisi jalan merupakan sesuatu yang sangat penting untuk diketahui informasinya oleh pengguna jalan karena bermanfaat untuk menghindari beberapa resiko yang akan terjadi jika pengguna jalan melewati kondisi yang rusak. Penelitian ini membahas tentang analisis pengelompokan kondisi permukaan jalan yang ada di Semarang khususnya. Kondisi permukaan jalan di beberapa titik yang rusak sering mengakibatkan kecelakaan bagi pengguna jalan oleh karena itu jika pengguna jalan dapat menghindari kondisi permukaan jalan maka dapat meminimalisir terjadinya resiko kecelakaan. Pada penelitiam ini menggunakan aplikasi Accelerometer yang berfungsi untuk pengambilan data. Sedangkan untuk pengelompokkan data menggunakan algoritma $K$-Means. Hasil data yang diperoleh sejumlah 2014 titik jalan yang rusak telah dikelompokkan menjadi 7 kecematan dengan hasil kecamatan Gayamsari merupakan daerah paling rawan rusak.
\end{abstract}

Keywords: Kondisi, permukaan, jalan, pengelompokkan, k-means

\section{PENDAhuluan}

Kondisi permukaan jalan yang berbahaya merupakan gangguan utama bagi pengguna transportasi yang ingin menggunakan jalan dengan aman dan nyaman. Baik pengemudi maupun dinas terkait menginginkan untuk memperbaiki kondisi jalan dengan cepat. Namun, kondisi ini harus diidentifikasi terlebih dahulu. [1]

Deteksi dan estimasi lubang adalah salah satu yang informasi yang penting untuk perencanaan perbaikan dan rehabilitasi yang tepat pada permukaan jalan. Perusahaan ataupun dinas terkait yang bertugas sebagai pemeliharaan jalan membutuhkan banyak petugas untuk mengumpulkan data secara manual dan membutuhkan banyak jam kerja untuk mengidentifikasi kerusakan jalan. Ada banyak faktor yang memengaruhi keputusan perbaikian jalan seperti tingkat lalu lintas, waktu hingga rehabilitasi atau pelapisan terjadwal, ketersediaan sumber daya manusia, peralatan, dan bahan. Efektivitas biaya dari keseluruhan perbaikan operasi dipengaruhi oleh biaya material, tenaga kerja, dan peralatan. Kunci pengambilan keputusan untuk rekonstruksi jalan atau tidak terletak pada deteksi dan estimasi kerusakan jalan dari informasi yang sudah dikumpulkan [2].

Android yang dirilis oleh Google telah menjadi sistem operasi seluler terbesar yang tersebar luas sampai saat ini. Ketersediaan IDE intuitif seperti Eclipse bersama dengan SDK yang kuat telah diperbarui secara teratur membuat Android tidak kekurangan pesona untuk para pengembang dan para profesional berpengalaman. Ada beberapa layanan yang dapat dimanfaatkankan datanya dari program cerdas yang diperoleh dari sejumlah sensor seperti chip GPS, Accelerometer, Giroskop

dll. Layanan tersebut telah membuat hidup jauh lebih mudah. Karena dapat diakses tnpa batas waktu dan tempat dari layanan deteksi lokasi hingga permainan.[3] Berdasarkan penelitian-penelitian terdahulu maka penelitian ini fokus pada identifikasi kondisi permukaan jalan dengan cara mengelompokkan ke beberapa kecamatan yang ada di kota Semarang. Dengan adanya pengelompokkan kondisi permukaan jalan tersebut diharapkan dapat menjadi referensi bagi dinas terkait untuk pengambilan keputusan perbaikan jalan yang diprioritaskan.

\section{METODE}

\subsection{K-Means}

Algoritma K-Means merupakan algoritma pengelompokan iterative yang melakukan partisi set data ke dalam sejumlah $\mathrm{K}$ cluster yang sudah ditetapkan di awal. Algoritma K-means sederhana untuk diimplementasikan dan dijalankan, relatif cepat, mudah beradaptasi, umum penggunaannya dalam praktek. Secara historis, K-means menjadi salah satu algoritma yang paling penting dalam data mining. [4]

Algoritma K-Means adalah algoritma yang terbaikdalam algoritma Partitional Clustering dan yang paling sering digunakan diantara algoritma Clustering lainnya, karena kesederhanaan dan efesiensinya [5]. 


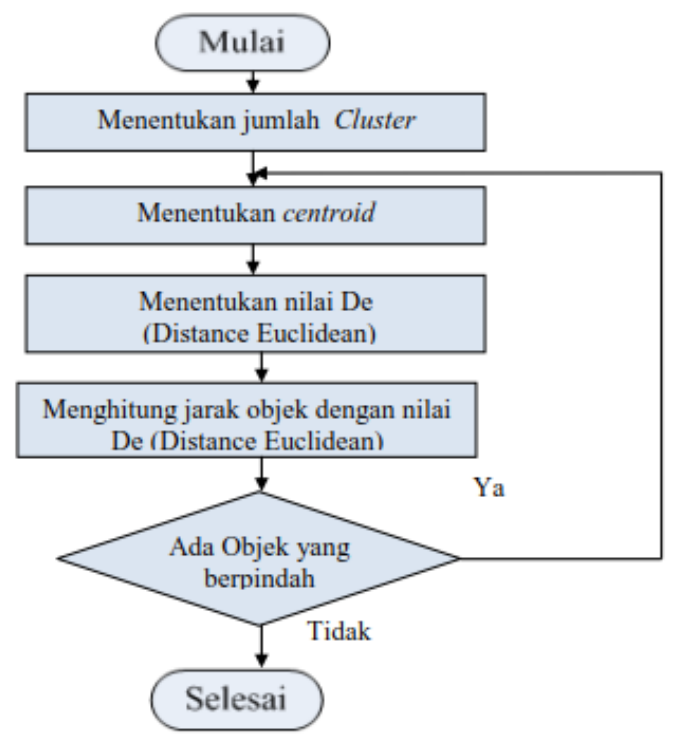

Gambar 1. Flowchart Algoritma Metode KMeansClustering [6]

\subsection{Tahapan Penelitian}

Pengumpulan data menggunakan aplikasi accelerometer dengan memanfaatkan sensor accelerometer pada android. Data yang terkumpul akan diolah dengan menggunakan algoritma k-means dengan tujuan untuk mengelompokkan ke beberapa kecamatan sehingga diketahui daerah rawan rusak. Tahapan pengolahan data sebagai berikut :

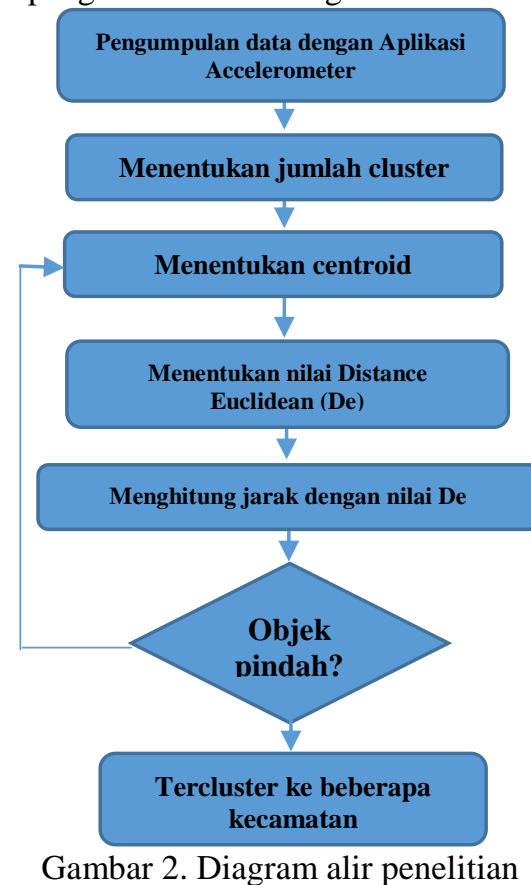

\section{HASIL DAN PEMBAHASAN}

\subsection{Inisialisasai Atribut Kecamatan dan Kelurahan}

Data yang dihasilkan dari aplikasi accelerometer sebanyak 2014 titik jalan rusak. Dari data tersebut akan dilakukan pengelompokkan per kecamatan. Tujuan dari pengelompokkan tersebut untuk mengetahui kecamatan , ana yang paling rawan rusak. Pengelompokkan kecamatan menggunakan algoritma K-mans. Percobaan dilakukan dengan menggunakan parameter-parameter berikut :

Jumlah cluster : 7

Jumlah data : 2014 (Sample 58 data)

Jumlah atribut $\quad: 4$

Tabel 1. Inisialisasi atribut kecamatan dan kelurahan

\begin{tabular}{|c|c|c|c|c|}
\hline No & Kecamatan & Inisial & Kelurahan & Inisial \\
\hline \multirow[t]{2}{*}{1} & Gayamsari & 1 & Sambirejo & 1 \\
\hline & & & $\begin{array}{l}\text { Pandean } \\
\text { Lamper }\end{array}$ & 1 \\
\hline \multirow[t]{2}{*}{2} & Genuk & 2 & $\begin{array}{l}\text { Muktiharjo } \\
\text { Lor }\end{array}$ & 2 \\
\hline & & & Gebang Sari & 2 \\
\hline \multirow[t]{5}{*}{3} & Pedurungan & 3 & Gemah & 3 \\
\hline & & & $\begin{array}{l}\text { Muktiharjo } \\
\text { Kidul }\end{array}$ & 3 \\
\hline & & & $\begin{array}{l}\text { Pedurungan } \\
\text { Lor }\end{array}$ & 3 \\
\hline & & & $\begin{array}{l}\text { Pedurungan } \\
\text { Tengah }\end{array}$ & 3 \\
\hline & & & $\begin{array}{l}\text { Tlogosari } \\
\text { Kulon }\end{array}$ & 3 \\
\hline \multirow[t]{3}{*}{4} & $\begin{array}{l}\text { Semarang } \\
\text { Selatan }\end{array}$ & 4 & Peterongan & 4 \\
\hline & & & Lamper Kidul & 4 \\
\hline & & & Lamper Lor & 4 \\
\hline 5 & $\begin{array}{l}\text { Semarang } \\
\text { Tengah }\end{array}$ & 5 & Brumbungan & 5 \\
\hline \multirow[t]{5}{*}{6} & $\begin{array}{l}\text { Semarang } \\
\text { Timur }\end{array}$ & 6 & Mlati Harjo & 6 \\
\hline & & & Karang Turi & 6 \\
\hline & & & $\begin{array}{l}\text { Karang } \\
\text { Tempel }\end{array}$ & 6 \\
\hline & & & Kebun Agung & 6 \\
\hline & & & Sari Rejo & 6 \\
\hline 7 & Tembalang & 7 & Tembalang & 7 \\
\hline
\end{tabular}

\subsection{Dataset}

Pengumpulan dataset menggunakan aplikasi accelerometer. Aplikasi tersebut memanfaatkan sensor accelerometer dan GPS yang ada di android untuk merekam ja;an yang tidak rata. Data yang direkam meliputi nama kelurahan, lattitude, dan longitude. Hasil dari pengumpulan data sebagai berikut : 
Tabel 2. Dataset Clustering

\begin{tabular}{|c|c|c|c|c|c|}
\hline No & Kecamatan & lat & long & kec & kel \\
\hline 1 & $\begin{array}{l}\text { Semarang } \\
\text { Timur }\end{array}$ & 6.96963 & 110.434 & 6.0 & 6.0 \\
\hline 2 & $\begin{array}{l}\text { Semarang } \\
\text { Timur }\end{array}$ & 6.96963 & 110.434 & 6.0 & 6.0 \\
\hline 3 & $\begin{array}{l}\text { Semarang } \\
\text { Timur }\end{array}$ & 6.96963 & 110.434 & 6.0 & 6.0 \\
\hline 4 & $\begin{array}{l}\text { Semarang } \\
\text { Timur }\end{array}$ & 6.96963 & 110.434 & 6.0 & 6.0 \\
\hline 5 & $\begin{array}{l}\text { Semarang } \\
\text { Timur }\end{array}$ & 6.96963 & 110.434 & 6.0 & 6.0 \\
\hline 6 & $\begin{array}{l}\text { Semarang } \\
\text { Timur }\end{array}$ & 6.96963 & 110.434 & 6.0 & 6.0 \\
\hline 7 & $\begin{array}{l}\text { Semarang } \\
\text { Timur }\end{array}$ & 6.96958 & 110.434 & 6.0 & 6.0 \\
\hline 8 & $\begin{array}{l}\text { Semarang } \\
\text { Timur }\end{array}$ & $\begin{array}{r}- \\
6.96958\end{array}$ & 110.434 & 6.0 & 6.0 \\
\hline 9 & $\begin{array}{l}\text { Semarang } \\
\text { Timur }\end{array}$ & 6.96958 & 110.434 & 6.0 & 6.0 \\
\hline 10 & $\begin{array}{l}\text { Semarang } \\
\text { Timur }\end{array}$ & 6.96958 & 110.434 & 6.0 & 6.0 \\
\hline 11 & $\begin{array}{l}\text { Semarang } \\
\text { Timur }\end{array}$ & 6.96962 & 110.434 & 6.0 & 6.0 \\
\hline 12 & $\begin{array}{l}\text { Semarang } \\
\text { Timur }\end{array}$ & 6.96962 & 110.434 & 6.0 & 6.0 \\
\hline 13 & $\begin{array}{l}\text { Semarang } \\
\text { Timur }\end{array}$ & 6.96962 & 110.434 & 6.0 & 6.0 \\
\hline 14 & $\begin{array}{l}\text { Semarang } \\
\text { Timur }\end{array}$ & 6.96963 & 110.434 & 6.0 & 6.0 \\
\hline 15 & $\begin{array}{l}\text { Semarang } \\
\text { Timur }\end{array}$ & 6.96963 & 110.434 & 6.0 & 6.0 \\
\hline 16 & $\begin{array}{l}\text { Semarang } \\
\text { Timur }\end{array}$ & 6.96963 & 110.434 & 6.0 & 6.0 \\
\hline 17 & $\begin{array}{l}\text { Semarang } \\
\text { Timur }\end{array}$ & 6.96963 & 110.434 & 6.0 & 6.0 \\
\hline 18 & $\begin{array}{l}\text { Semarang } \\
\text { Timur }\end{array}$ & 6.96963 & 110.434 & 6.0 & 6.0 \\
\hline 19 & $\begin{array}{l}\text { Semarang } \\
\text { Timur }\end{array}$ & 6.96965 & 110.434 & 6.0 & 6.0 \\
\hline 20 & $\begin{array}{l}\text { Semarang } \\
\text { Timur }\end{array}$ & 6.96965 & 110.434 & 6.0 & 6.0 \\
\hline 21 & $\begin{array}{l}\text { Semarang } \\
\text { Timur }\end{array}$ & 6.96966 & 110.435 & 6.0 & 6.0 \\
\hline 22 & $\begin{array}{l}\text { Semarang } \\
\text { Timur }\end{array}$ & 6.96966 & 110.435 & 6.0 & 6.0 \\
\hline 23 & $\begin{array}{l}\text { Semarang } \\
\text { Timur }\end{array}$ & 6.96966 & 110.435 & 6.0 & 6.0 \\
\hline 24 & $\begin{array}{l}\text { Semarang } \\
\text { Timur }\end{array}$ & $\begin{array}{r}- \\
6.96966\end{array}$ & 110.435 & 6.0 & 6.0 \\
\hline 25 & $\begin{array}{l}\text { Semarang } \\
\text { Timur }\end{array}$ & 6.96963 & 110.435 & 6.0 & 6.0 \\
\hline 26 & $\begin{array}{l}\text { Semarang } \\
\text { Timur }\end{array}$ & 6.96963 & 110.435 & 6.0 & 6.0 \\
\hline 27 & $\begin{array}{l}\text { Semarang } \\
\text { Timur }\end{array}$ & 6.96963 & 110.435 & 6.0 & 6.0 \\
\hline 28 & $\begin{array}{l}\text { Semarang } \\
\text { Timur }\end{array}$ & 6.96966 & 110.435 & 6.0 & 6.0 \\
\hline
\end{tabular}

\begin{tabular}{|c|c|c|c|c|c|}
\hline 29 & $\begin{array}{l}\text { Semarang } \\
\text { Timur }\end{array}$ & 6.96966 & 110.435 & 6.0 & 6.0 \\
\hline 30 & $\begin{array}{l}\text { Semarang } \\
\text { Timur }\end{array}$ & $\begin{array}{r}- \\
6.96966\end{array}$ & 110.435 & 6.0 & 6.0 \\
\hline 31 & $\begin{array}{l}\text { Semarang } \\
\text { Timur }\end{array}$ & 6.96966 & 110.435 & 6.0 & 6.0 \\
\hline 32 & $\begin{array}{l}\text { Semarang } \\
\text { Timur }\end{array}$ & 6.98481 & 110.431 & 6.0 & 6.0 \\
\hline 33 & $\begin{array}{l}\text { Semarang } \\
\text { Timur }\end{array}$ & $\begin{array}{r}- \\
6.98481\end{array}$ & 110.431 & 6.0 & 6.0 \\
\hline 34 & $\begin{array}{l}\text { Semarang } \\
\text { Timur }\end{array}$ & $\begin{array}{r}- \\
6.98481\end{array}$ & 110.431 & 6.0 & 6.0 \\
\hline 35 & $\begin{array}{l}\text { Semarang } \\
\text { Timur }\end{array}$ & $\begin{array}{r}- \\
6.98457\end{array}$ & 110.432 & 6.0 & 6.0 \\
\hline 36 & $\begin{array}{l}\text { Semarang } \\
\text { Timur }\end{array}$ & $\begin{array}{r}- \\
6.98457\end{array}$ & 110.432 & 6.0 & 6.0 \\
\hline 37 & $\begin{array}{l}\text { Semarang } \\
\text { Timur }\end{array}$ & $\begin{array}{r}- \\
6.98399\end{array}$ & 110.432 & 6.0 & 6.0 \\
\hline 38 & $\begin{array}{l}\text { Semarang } \\
\text { Timur }\end{array}$ & $\begin{array}{r}- \\
6.98317\end{array}$ & 110.431 & 6.0 & 6.0 \\
\hline 39 & $\begin{array}{l}\text { Semarang } \\
\text { Timur }\end{array}$ & 6.98249 & 110.432 & 6.0 & 6.0 \\
\hline 40 & $\begin{array}{l}\text { Semarang } \\
\text { Timur }\end{array}$ & 6.98249 & 110.432 & 6.0 & 6.0 \\
\hline 41 & $\begin{array}{l}\text { Semarang } \\
\text { Timur }\end{array}$ & 6.98175 & 110.431 & 6.0 & 6.0 \\
\hline 42 & $\begin{array}{l}\text { Semarang } \\
\text { Timur }\end{array}$ & $\begin{array}{r}- \\
6.98175 \\
\end{array}$ & 110.431 & 6.0 & 6.0 \\
\hline 43 & $\begin{array}{l}\text { Semarang } \\
\text { Timur }\end{array}$ & 6.98071 & 110.431 & 6.0 & 6.0 \\
\hline 44 & $\begin{array}{l}\text { Semarang } \\
\text { Timur }\end{array}$ & $\begin{array}{r}- \\
6.98071\end{array}$ & 110.431 & 6.0 & 6.0 \\
\hline 45 & $\begin{array}{l}\text { Semarang } \\
\text { Timur }\end{array}$ & $\begin{array}{r}- \\
6.98071\end{array}$ & 110.431 & 6.0 & 6.0 \\
\hline 46 & $\begin{array}{l}\text { Semarang } \\
\text { Timur }\end{array}$ & $\begin{array}{r}- \\
6.98013\end{array}$ & 110.431 & 6.0 & 6.0 \\
\hline 47 & $\begin{array}{l}\text { Semarang } \\
\text { Timur }\end{array}$ & 6.98013 & 110.431 & 6.0 & 6.0 \\
\hline 48 & $\begin{array}{l}\text { Semarang } \\
\text { Timur }\end{array}$ & 6.98013 & 110.431 & 6.0 & 6.0 \\
\hline 49 & $\begin{array}{l}\text { Semarang } \\
\text { Timur }\end{array}$ & 6.98013 & 110.431 & 6.0 & 6.0 \\
\hline 50 & $\begin{array}{l}\text { Semarang } \\
\text { Timur }\end{array}$ & 6.98013 & 110.431 & 6.0 & 6.0 \\
\hline 51 & $\begin{array}{l}\text { Semarang } \\
\text { Timur }\end{array}$ & -6.9795 & 110.431 & 6.0 & 6.0 \\
\hline 52 & Pedurungan & 6.97451 & 110.445 & 3.0 & 3.0 \\
\hline 53 & Pedurungan & 6.97451 & 110.445 & 3.0 & 3.0 \\
\hline 54 & Pedurungan & $\begin{array}{r}- \\
6.97451 \\
\end{array}$ & 110.445 & 3.0 & 3.0 \\
\hline 56 & Pedurungan & 6.97482 & 110.445 & 3.0 & 3.0 \\
\hline 57 & Pedurungan & $6.97482^{-}$ & 110.445 & 3.0 & 3.0 \\
\hline 58 & Pedurungan & $6.97482^{-}$ & 110.445 & 3.0 & 3.0 \\
\hline
\end{tabular}




\begin{tabular}{|r|l|r|l|l|l|}
\hline 59 & Pedurungan & 6.97482 & 110.445 & 3.0 & 3.0 \\
\hline 60 & Pedurungan & 6.97482 & 110.445 & 3.0 & 3.0 \\
\hline 61 & Pedurungan & 6.97482 & 110.445 & 3.0 & 3.0 \\
\hline 62 & Pedurungan & 6.97482 & 110.445 & 3.0 & 3.0 \\
\hline 63 & Pedurungan & 6.97482 & 110.445 & 3.0 & 3.0 \\
\hline 64 & Pedurungan & 6.97482 & 110.445 & 3.0 & 3.0 \\
\hline 65 & Pedurungan & 6.97501 & 110.445 & 3.0 & 3.0 \\
\hline 66 & Pedurungan & 6.97501 & 110.445 & 3.0 & 3.0 \\
\hline 67 & Pedurungan & 6.97501 & 110.445 & 3.0 & 3.0 \\
\hline 68 & Pedurungan & 6.97501 & 110.445 & 3.0 & 3.0 \\
\hline 69 & Pedurungan & 6.97501 & 110.445 & 3.0 & 3.0 \\
\hline 70 & Pedurungan & 6.97501 & 110.445 & 3.0 & 3.0 \\
\hline
\end{tabular}

\subsection{Perhitungan K-Means}

Pada tahap ini merupakan tahap dimana dataset yang telah diinisialisasi diatas akan diolah untuk pengelompokkan kondisi jalan dengan algoritma kmeans. Hasilnya sebagai berikut :

a. Iterasi ke-1

1. Penentuan pusat awal cluster

Untuk penentuan awal di asumsikan:

Diambil data ke- 26 sebagai pusat Cluster Ke-1:

$(-6.96963,110.445,6.0,6.0)$

Diambil data ke- 41 sebagai pusat Cluster Ke-2:

( 6.97482, 110.445, 3.0, 3.0)

\section{Perhitungan jarak pusat cluster}

Untuk mengukur jarak antara data dengan pusat cluster digunakan Euclidian distance, kemudian akan didapatkan matrik jarak yaitu $\mathrm{C} 1$ dan $\mathrm{C} 2$ sebagai berikut :

\section{Rumus Euclidian distance}

$$
\mathrm{d}(\mathrm{x}, \mathrm{y})=|x-y|=\sqrt{\sum_{i=1}^{n}\left(x_{i}-y_{i}\right)^{2}} \text {. }
$$

Tabel 3. Hasil Perhitungan Jarak Cluster

\begin{tabular}{|c|c|c|c|c|}
\hline No & Kecamatan & C1 & $\mathrm{C2}$ & $\begin{array}{c}\text { Jarak } \\
\text { Terpendek }\end{array}$ \\
\hline 1 & $\begin{array}{l}\text { Semarang } \\
\text { Timur }\end{array}$ & 0.000001 & 12.005311 & 0.000001 \\
\hline 2 & $\begin{array}{l}\text { Semarang } \\
\text { Timur }\end{array}$ & 0.000001 & 12.005311 & 0.000001 \\
\hline 3 & $\begin{array}{l}\text { Semarang } \\
\text { Timur }\end{array}$ & 0.000001 & 12.005311 & 0.000001 \\
\hline 4 & $\begin{array}{l}\text { Semarang } \\
\text { Timur }\end{array}$ & 0.000001 & 12.005311 & 0.000001 \\
\hline 5 & $\begin{array}{l}\text { Semarang } \\
\text { Timur }\end{array}$ & 0.000001 & 12.005311 & 0.000001 \\
\hline 6 & $\begin{array}{l}\text { Semarang } \\
\text { Timur }\end{array}$ & 0.000001 & 12.005311 & 0.000001 \\
\hline 7 & $\begin{array}{l}\text { Semarang } \\
\text { Timur }\end{array}$ & 0.000051 & 12.005361 & 0.000051 \\
\hline 8 & $\begin{array}{l}\text { Semarang } \\
\text { Timur }\end{array}$ & 0.000051 & 12.005361 & 0.000051 \\
\hline 9 & $\begin{array}{l}\text { Semarang } \\
\text { Timur }\end{array}$ & 0.000051 & 12.005361 & 0.000051 \\
\hline 10 & $\begin{array}{l}\text { Semarang } \\
\text { Timur }\end{array}$ & 0.000051 & 12.005361 & 0.000051 \\
\hline 11 & $\begin{array}{l}\text { Semarang } \\
\text { Timur }\end{array}$ & 0.000011 & 12.005321 & 0.000011 \\
\hline 12 & $\begin{array}{l}\text { Semarang } \\
\text { Timur }\end{array}$ & 0.000011 & 12.005321 & 0.000011 \\
\hline 13 & $\begin{array}{l}\text { Semarang } \\
\text { Timur }\end{array}$ & 0.000011 & 12.005321 & 0.000011 \\
\hline 14 & $\begin{array}{l}\text { Semarang } \\
\text { Timur }\end{array}$ & 0.000001 & 12.005311 & 0.000001 \\
\hline 15 & $\begin{array}{l}\text { Semarang } \\
\text { Timur }\end{array}$ & 0.000001 & 12.005311 & 0.000001 \\
\hline 16 & $\begin{array}{l}\text { Semarang } \\
\text { Timur }\end{array}$ & 0.000001 & 12.005311 & 0.000001 \\
\hline 17 & $\begin{array}{l}\text { Semarang } \\
\text { Timur }\end{array}$ & 0.000001 & 12.005311 & 0.000001 \\
\hline 18 & $\begin{array}{l}\text { Semarang } \\
\text { Timur }\end{array}$ & 0.000001 & 12.005311 & 0.000001 \\
\hline 19 & $\begin{array}{l}\text { Semarang } \\
\text { Timur }\end{array}$ & 0.000021 & 12.005291 & 0.000021 \\
\hline 20 & $\begin{array}{l}\text { Semarang } \\
\text { Timur }\end{array}$ & 0.000021 & 12.005291 & 0.000021 \\
\hline 21 & $\begin{array}{l}\text { Semarang } \\
\text { Timur }\end{array}$ & 0.000030 & 12.00526 & 0.000030 \\
\hline 22 & $\begin{array}{l}\text { Semarang } \\
\text { Timur }\end{array}$ & 0.000030 & 12.00526 & 0.000030 \\
\hline 23 & $\begin{array}{l}\text { Semarang } \\
\text { Timur }\end{array}$ & 0.000030 & 12.00526 & 0.000030 \\
\hline 24 & $\begin{array}{l}\text { Semarang } \\
\text { Timur }\end{array}$ & 0.000030 & 12.00526 & 0.000030 \\
\hline 25 & $\begin{array}{l}\text { Semarang } \\
\text { Timur }\end{array}$ & 0.000000 & 12.00529 & 0.000000 \\
\hline 26 & $\begin{array}{l}\text { Semarang } \\
\text { Timur }\end{array}$ & 0.000000 & 12.00529 & 0.000000 \\
\hline 27 & $\begin{array}{l}\text { Semarang } \\
\text { Timur }\end{array}$ & 0.000000 & 12.00529 & 0.000000 \\
\hline 28 & $\begin{array}{l}\text { Semarang } \\
\text { Timur }\end{array}$ & 0.000030 & 12.00526 & 0.000030 \\
\hline 29 & $\begin{array}{l}\text { Semarang } \\
\text { Timur }\end{array}$ & 0.000030 & 12.00526 & 0.000030 \\
\hline 30 & $\begin{array}{l}\text { Semarang } \\
\text { Timur }\end{array}$ & 0.000030 & 12.00526 & 0.000030 \\
\hline 31 & $\begin{array}{l}\text { Semarang } \\
\text { Timur }\end{array}$ & 0.000030 & 12.00526 & 0.000030 \\
\hline
\end{tabular}




\begin{tabular}{|c|c|c|c|c|}
\hline No & Kecamatan & C1 & $\mathrm{C2}$ & $\begin{array}{c}\text { Jarak } \\
\text { Terpendek } \\
\end{array}$ \\
\hline 32 & $\begin{array}{l}\text { Semarang } \\
\text { Timur }\end{array}$ & 0.015196 & 12.010186 & 0.015196 \\
\hline 33 & Pedurungan & 12.015196 & 0.010186 & 0.010186 \\
\hline 34 & Pedurungan & 12.015196 & 0.010186 & 0.010186 \\
\hline 35 & Pedurungan & 12.014949 & 0.009919 & 0.009919 \\
\hline 36 & Pedurungan & 12.014949 & 0.009919 & 0.009919 \\
\hline 37 & Pedurungan & 12.014369 & 0.009339 & 0.009339 \\
\hline 38 & Pedurungan & 12.013556 & 0.008546 & 0.008546 \\
\hline 39 & Pedurungan & 12.012869 & 0.007839 & 0.007839 \\
\hline 40 & Pedurungan & 12.012869 & 0.007839 & 0.007839 \\
\hline 41 & Pedurungan & 12.012136 & 0.007126 & 0.007126 \\
\hline 42 & Pedurungan & 12.012136 & 0.007126 & 0.007126 \\
\hline 43 & Pedurungan & 12.011096 & 0.006086 & 0.006086 \\
\hline 44 & Pedurungan & 12.011096 & 0.006086 & 0.006086 \\
\hline 45 & Pedurungan & 12.011096 & 0.006086 & 0.006086 \\
\hline 46 & Pedurungan & 12.010516 & 0.005506 & 0.005506 \\
\hline 47 & Pedurungan & 12.010516 & 0.005506 & 0.005506 \\
\hline 48 & Pedurungan & 12.010516 & 0.005506 & 0.005506 \\
\hline 49 & Pedurungan & 12.010516 & 0.005506 & 0.005506 \\
\hline 50 & Pedurungan & 12.010516 & 0.005506 & 0.005506 \\
\hline 51 & Pedurungan & 12.009886 & 0.004876 & 0.004876 \\
\hline 52 & Pedurungan & 12.004980 & 0.00031 & 0.000310 \\
\hline 53 & Pedurungan & 12.004980 & 0.00031 & 0.000310 \\
\hline 54 & Pedurungan & 12.004980 & 0.00031 & 0.000310 \\
\hline 56 & Pedurungan & 12.005290 & 0 & 0.000000 \\
\hline 57 & Pedurungan & 12.005290 & 0 & 0.000000 \\
\hline 58 & Pedurungan & 12.005290 & 0 & 0.000000 \\
\hline 59 & Pedurungan & 12.005290 & 0 & 0.000000 \\
\hline 60 & Pedurungan & 12.005290 & 0 & 0.000000 \\
\hline 61 & Pedurungan & 12.005290 & 0 & 0.000000 \\
\hline 62 & Pedurungan & 12.005290 & 0 & 0.000000 \\
\hline 63 & Pedurungan & 12.005290 & 0 & 0.000000 \\
\hline 64 & Pedurungan & 12.005290 & 0 & 0.000000 \\
\hline 65 & Pedurungan & 12.005480 & 0.00019 & 0.000190 \\
\hline 66 & Pedurungan & 12.005480 & 0.00019 & 0.000190 \\
\hline 67 & Pedurungan & 12.005480 & 0.00019 & 0.000190 \\
\hline 68 & Pedurungan & 12.005480 & 0.00019 & 0.000190 \\
\hline 69 & Pedurungan & 12.005480 & 0.00019 & 0.000190 \\
\hline 70 & Pedurungan & 12.005480 & 0.00019 & 0.000190 \\
\hline
\end{tabular}

\section{Pengelompokkan data}

Jarak hasil perhitungan akan dilakukan perbandingan dan dipilih jarak terdekat antara data dengan pusat cluster, jarak ini menunjukkan bahwa data tersebut berada dalam satu kelompok dengan pusat cluster terdekat. Berikut ini akan ditampilkan data matriks pengelompokkan group, nilai 1 berarti data tersebut berada dalam group.

Tabel 4. Pengelompokkan data G1

\begin{tabular}{|c|c|c|}
\hline No & $\mathrm{C} 1$ & $\mathrm{C} 2$ \\
\hline 1 & 1 & 0 \\
\hline 2 & 1 & 0 \\
\hline 3 & 1 & 0 \\
\hline 4 & 1 & 0 \\
\hline 5 & 1 & 0 \\
\hline 6 & 1 & 0 \\
\hline 7 & 1 & 0 \\
\hline 8 & 1 & 0 \\
\hline 9 & 1 & 0 \\
\hline 10 & 1 & 0 \\
\hline 11 & 1 & 0 \\
\hline 12 & 1 & 0 \\
\hline 13 & 1 & 0 \\
\hline 14 & 1 & 0 \\
\hline 15 & 1 & 0 \\
\hline 16 & 1 & 0 \\
\hline 17 & 1 & 0 \\
\hline 18 & 1 & 0 \\
\hline 19 & 1 & 0 \\
\hline 20 & 1 & 0 \\
\hline 21 & 1 & 0 \\
\hline 22 & 1 & 0 \\
\hline 23 & 1 & 0 \\
\hline 24 & 1 & 0 \\
\hline 25 & 1 & 0 \\
\hline 26 & 1 & 0 \\
\hline 27 & 1 & 0 \\
\hline 28 & 1 & 0 \\
\hline 29 & 1 & 0 \\
\hline 30 & 1 & 0 \\
\hline 31 & 1 & 0 \\
\hline 32 & 1 & 0 \\
\hline 33 & 0 & 1 \\
\hline 34 & 0 & 1 \\
\hline 35 & 0 & 1 \\
\hline 36 & 0 & 1 \\
\hline 37 & 0 & 1 \\
\hline
\end{tabular}




\begin{tabular}{|c|c|c|}
\hline 38 & 0 & 1 \\
\hline 39 & 0 & 1 \\
\hline 40 & 0 & 1 \\
\hline 41 & 0 & 1 \\
\hline 42 & 0 & 1 \\
\hline 43 & 0 & 1 \\
\hline 44 & 0 & 1 \\
\hline 45 & 0 & 1 \\
\hline 46 & 0 & 1 \\
\hline 47 & 0 & 1 \\
\hline 48 & 0 & 1 \\
\hline 49 & 0 & 1 \\
\hline 50 & 0 & 1 \\
\hline 51 & 0 & 1 \\
\hline 52 & 0 & 1 \\
\hline 53 & 0 & 1 \\
\hline 54 & 0 & 1 \\
\hline 56 & 0 & 1 \\
\hline 57 & 0 & 1 \\
\hline 58 & 0 & 1 \\
\hline 59 & 0 & 1 \\
\hline 60 & 0 & 1 \\
\hline 61 & 0 & 1 \\
\hline 62 & 0 & 1 \\
\hline 63 & 0 & 1 \\
\hline 64 & 0 & 1 \\
\hline 65 & 0 & 1 \\
\hline 66 & 0 & 1 \\
\hline 67 & 0 & 1 \\
\hline 68 & 0 & 1 \\
\hline 69 & 0 & 1 \\
\hline 70 & 0 & 1 \\
\hline
\end{tabular}

\section{Penentuan pusat cluster baru}

Setelah diketahui anggota tiap-tiap cluster kemudian pusat cluster baru dihitung berdasarkan data anggota tiap-tiap cluster sesuai dengan rumus pusat anggota cluster. Sehingga didapatkan perhitungan sebagai berikut :

Cluster Baru ke-1 : (-6.974666, 110.436119, 4.4, 4.4) Cluster Baru ke-2 : $(-6.972320,110.44,4.5,4.5)$ Iterasi $\mathrm{Ke}-2$

5. Ulangi langkah ke 2 (kedua) hingga posisi data tidak mengalami perubahan. Pada percobaan penelitian ini iterasi sampai pada iterasi ke 3 dimana iterasi ke 2 sama dengan hasil iterasi ke 3. Kesimpulannya hasil clustering telah mencapai stabil dan konvergen dimana C1 merupakan kecamatan Semarang Selatan dengan jumlah titik jalan berlubang sebanyak 32 dan C2 merupakan kecamatan Pedurungan dengan jumlah titik jalan berlubang sebanyak 37.

\subsection{Implementasi K-Means Menggunkan Rapidminer}

Tahapan implementasi algoritma k-means menggunakan Rapid Miner. Berikut adalah hasil implementasinya :

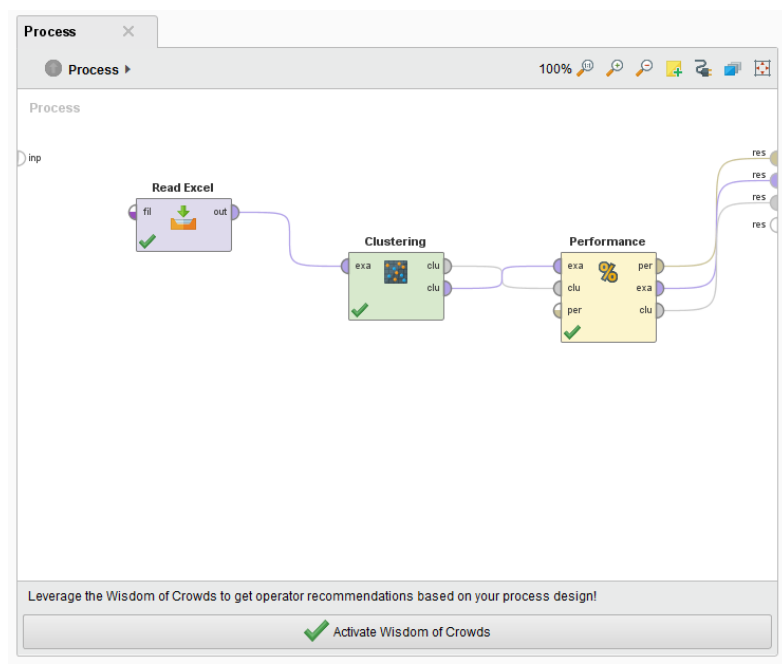

Gambar 2 Implementasi Rapid Miner

Pertama menghubungkan dataset yang bertipe excel dengan operator k-means, kemudian operator kmeans dihubungkan dengan operator Performance distance. Percobaan ini menggunakan atribut longitude, lattitude kelurahan dan kecamatan. Hasil dari eksekusi gambar diatas dapat dilihat dengan Chart dibawah ini :

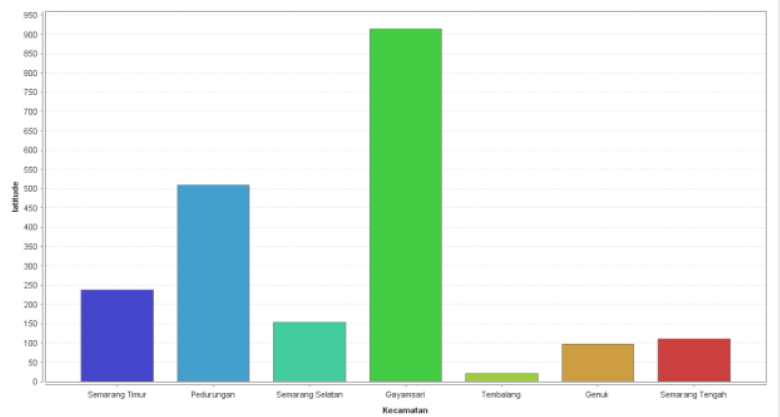

Gambar 4 Hasil Eksekusi 
Pada grafik diatas menjelaskan tentang hasil pengelompokkan data jalan berlubang yang berjumlah 2014 titik. Dari hasil grafik dapat disimpulkan bahwa kecamatan Gayamsari merupakan daerah paling rawan jalan berlubang. Karena terlihat grafik kecamatan Gayamsari paling tinggi.

\section{KESIMPULAN}

Aplikasi Accelerometer dapat menyaring data yang direkam oleh sensor accelerometer sehingga sistem tersebut dapat menyaring data kondisi permukaan jalan yang perlu diperbaiki. Sistem tersebut dilengkapi sensor GPS yang dapat memberikan informasi mengenai titik lokasi jalan yang perlu diperbaiki. Pengumpulan data dilakukan pada wilayah Semarang. Hasil dari pengumpulan data tersebut digunakan untuk clustering. Tahapan clustering mengelompokkan jalan berlubang per kecamatan. Hasilnya dari 7 kecamatan terdapat satu kecamatan yang paling rawan jalan rusak yaitu kecamatan Gayamsari. Untuk penelitian selanjutnya diharapkan dapat menguji akurasi dari penerapan algoritma k-means. Sehingga jika akurasi yang dihasilkan sudah baik maka dapat diimplementasikan ke dalam aplikasi.

\section{DAFTAR PUSTAKA}

[1] A. Mednis, G. Strazdins, R. Zviedris, G. Kanonirs, and L. Selavo, "Real time pothole detection using Android smartphones with accelerometers," 2011 Int. Conf. Distrib. Comput. Sens. Syst. Work. DCOSS'11, 2011.

[2] Emir, Semir dan Alvin, "Pothole Detection with image procesing and spectral clustering", Recent Advances in Computer Science and Networking, ISBN: 978-960-474-336-0

[3] Aniket, Nitish, Sagar dan Dr.Nupur, "Pothole Detection System Using Machine Learning on Android", International Journal of Emerging Technology and Advanced Engineering, Volume 4, Issue 7, 2014

[4] Wu, X and Kumar V., 2009, The Top Ten Algorithms in Data Mining, Chapman and Hall, Minnesota.
[5] Irwan Budiman, Toni Prahasto, and Yuli Christyono, "DATA CLUSTERING MENGGUNAKAN METODOLOGI CRISP-DM UNTUK PENGENALAN POLA PROPORSI PELAKSANAAN TRIDHARMA," in Seminar Nasional Aplikasi Teknologi Informasi 2012 (SNATI 2012), Yogyakarta, 2012.

[6] Nugraheni, Y. 2011. Data Mining degan Metode Fuzzy Untuk Customer Relationship Management (CRM) pada Perusahaan Retail. Universitas Udayana 